\title{
La donna è mobile
}

\author{
Ord om hvor flyktig og ustadig kvinnesinnet er, er kjent fra Vergil til Håvamål. At også kvinnens kropp avviker \\ fra «det normale» når det gjelder symptomer og prøveresultater i takt med menstruasjonssyklusen, drøftes \\ i Tidsskriftet nr. 21/1932. Artikkelforfatteren fant flere tilfeller av falskt negativt resultat hvis tuberkulinprøven \\ ble tatt under menstruasjonen (Tidsskr Nor Lægeforen 1932; 52: 1311-8).
}

\section{En undersøkelse av v. Pirquets reaksjon under menstruasjon samt om valg av tuberkulin.}

\author{
Av Herman Thrap-Meyer, Stavern.
}

Såvel i lærebøker som i spesialartikler fremheves ofte den store innflytelse menstruasjon og ovulasjon har i kvinnens biologi, ganske spesielt på det immun-biologiske område ; men det er påfallende hvor relativt få serieundersøkelser der er foretatt. De mere eller mindre svevende angivelser over de biologiske prosessers sykliske forløp i forhold til menstruasjonen er for en stor del basert på enkeltiakttagelser, og det er derfor vanskelig å danne seg et eksakt billede av menstruasjonens virkelige innflydelse. (...)

Av Géza Gális undersøkelser fra 1926 fremgår det tydelig at opfatningen av forholdet mellem menstruasjon og allergitilstanden hos tuberkuløse er noget vekslende. Karczag (4 kasus) fant at allergien var svakest 10 til 14 dager før menstruasjonen, blev noget sterkere under menstruasjonen for derpå å avta noget før den på ny steg. Selter fant at tuberkulinømfintligheten avtok sterkt første menstruasjonsdag, men begynte å øke allerede 2 nen dag, for atter å nå sitt almindelige nivå 2 dager efter avsluttet menstruasjon. Couland hevder, at tuberkulinallergien under menstruasjonen enten avtar eller mangler, men øke gjør den aldri.

For den praktiserende læge er det imidlertid den sviktende allergi som er av betydning. En positiv tuberkulinreaksjon er dog tross alt positiv, og dens verdi er dermed gitt. (Jeg ser her helt bort fra de uspesifikke tuberkulinreaksjoner.) En negativ reaksjon kan derimot vekke tvil. En særskilt interesse knytter sig selvsagt til tuberkulinallergien påvist ved v. Pirquets reaksjon, den reaksjon som jo oftest anvendes, især ved masseundersøkelser.

Ut fra dette resonnementet har jeg utført v. Pirquets reaksjon på de menstruerende kvinnelige patienter i Kysthospitalet i løpet av $1 / 2$ år. Reaksjonene er utført etter den lineære ripemetode 1ste menstruasjonsdag og 10 dager senere, det vil si i almindelighet 5-7 dager etter avsluttet menstruasjon. Dette tidspunkt tilsvarer ifølge en undersøkelse av Geller i 1928 den periode innen den mensuelle syklus $\mathrm{i}$ hvilken blodets baktericide evne og leukocytenes antall er jevnest. I alt er 49 kvinner undersøkt i tilsammen 158 menstruasjonsperioder. 4 kvinner led ikke av tuberkulose og var konstant v. Pirquet-negative. Disse 4 representerer 8 perioder. Tilbake blir da 45 kvinner hvis v. Pirquet reaksjon i og utenfor menstruasjonsfasen er undersøkt 150 ganger. Av de 45 kvinner er 17 undersøkt bare i 1 periode, mens 28 er undersøkt i 2 til 7 perioder. Hos 10 kvinner fant jeg inkonstant for-

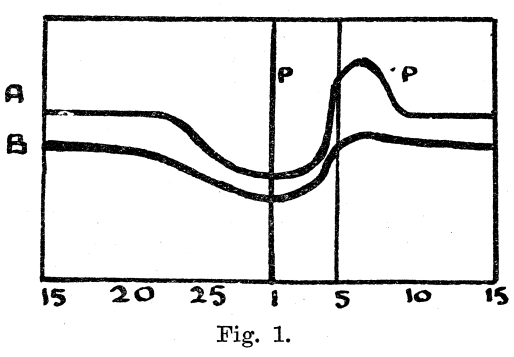

Kurvene viser efter Gellers unders $\varnothing$ kelser: A. Blodets baktericide evne dens variasjon innen den menstruelle syklus. Feltet mellem de vertikale streker angir menstruasjonstiden. B. Leukocytenes varierende antall $\mathrm{i}$ blodet. P. angir tidspunktene for mine unders $\varnothing$ kelser.

bigående negativ v. Pirquet reaksjon under menstruasjonen i alt 14 ganger. Hvad angår avgjørelsen : Positiv eller negativ, har jeg holdt mig til Axel Strøms angivelser : «Efter 48 timer er enhver reaksjon som er tydelig og følbar - ikke bare spor - sikkert positiv.» (...)

Men anerkjennes den menstruelt svekkede, eventuelt med v. Pirquets reaksjon ikke påviselige allergi som en mulig feilkilde, da tvinger det spørsmål sig uvilkårlig frem : Når skal v. Pirquets reaksjon utføres hos voksne kvinner for at resultatet skal gi det beste uttrykk for forholdet mellem tuberkuløst infiserte og ikke infiserte?

Så vist mig bekjent er dette forhold ennu et terra incognita med vide felter for gjetning. Gellers før omtalte undersøkelser kan kanskje peke i en bestemt retning. Han undersøkte blodets baktericide evne og dens variasjoner i og utenfor menstruasjonsfasen. Resultatet var en kurve som begynner å synke i præmenstruum, for å nå sitt laveste punkt 1ste og 2nen menstruasjonsdag. Derpå stiger den raskt og når sitt maksimum 7 dager efter 1 ste menstruasjonsdag. Derpå synker den i løpet av 3-4 dager ned til det jevne intermenstruelle nivå. Imidlertid er jo blodets baktericide evne og den allergiske tilstand begge bare delfenomener av det vi med en felles betegnelse kan kalle organismens immunitetsforhold. Såvel Couland som Selters og mine undersøkelser kan tyde på at disse fenomener varierer parallelt. Konsekvensen herav skulde da være å anbefale v. Pirquets reaksjon hos voksne kvinner utført mellem 5te og ca. 20de dag regnet fra 1ste menstruasjonsdag. (Se kurven.) 